\title{
Efektivitas pembelajaran IPS melalui implementasi metode jigsaw ditinjau dari aktivitas dan hasil belajar siswa
}

\author{
Elis Suryani *, Aman Aman \\ Program Studi Pendidikan Kewarganegaraan, Pascasarjana, Universitas Negeri Yogyakarta. \\ Jalan Colombo No. 1, Karangmalang, Yogyakarta 55281, Indonesia \\ Elissuryani20@gmail.com \\ * Corresponding Author
}

\section{ARTICLE INFO}

\section{Article History}

Received:

16 December 2017;

Revised:

23 May 2019;

Accepted:

26 September 2019

\section{Keywords}

Metode jigsaw; Metode ceramah; Aktivitas belajar; Hasil belajar; Jigsaw method; Lecturing method; Learning activity; Learning output

\begin{abstract}
ABSTRAK
Penelitian ini bertujuan untuk mengetahui ada tidaknya perbedaan aktivitas dan hasil belajar IPS siswa menggunakan metode Jigsaw dibandingkan menggunakan metode Ceramah di Kelas VIII SMP Negeri 1 Masaran Sragen, serta keefektifan metode Jigsaw terhadap aktivitas dan belajar dalam pembelajaran IPS siswa kelas VIII SMP Negeri 1 Masaran Sragen. Penelitian ini merupakan True Experimental Design dengan desain Pretest-Posttest Control Group Design. Analisis data menggunakan analisis statistik independent sample t-test dengan bantuan program SPSS 16.00 for Windows Hasil penelitian menunjukkan adanya perbedaan aktivitas dan hasil belajar dalam pembelajaran IPS menggunakan metode Jigsaw dibandingkan menggunakan metode Ceramah di Kelas VIII SMP Negeri 1 Masaran Sragen. Hal ini ditunjukkan dari hasil uji t pada aktivitas dan hasil belajar. Besar ukuran efek metode Jigsaw terhadap aktivitas dan hasil belajar memberikan efek sedang. Hal ini berarti, metode Jigsaw efektif terhadap aktivitas dan hasil belajar dalam pembelajaran IPS siswa kelas VIII SMP Negeri 1 Masaran Sragen. Pembelajaran menggunakan metode Jigsaw membuat peserta didik aktif yang menimbulkan kerja sama yang dapat meningkatkan keterlibatan siswa dengan melakukan aktivitas mereka sendiri-sendiri. Cooperative learning memberi kesempatan siswa untuk mengembangkan atau menciptakan ideide yang dapat dipelajari sendiri oleh siswa yang akhirnya menambah pengetahuan siswa dibandingkan jika siswa hanya mendengarkan penjelasan dari guru.
\end{abstract}

This study aimed to find out the differences in the comparison of using IPS learning activity and output using Jigsaw and lecturing method at SMP Negeri 1 Masaran Sragen Grade VIII and the effectiveness of Jigsaw method on students' learning activity and output in IPS learning at SMP Negeri 1 Masaran Sragen Grade VIII. This study is true experimental with Pretest-Posttest Control Group Design. Data analysis technique used statistic analysis of independent sample t-test towards gain score in assistance with SPSS 16.00 for Windows program. The study showed the differences in learning activity and learning output in using Jigsaw method in comparison with lecturing method at SMP Negeri 1 Masaran Sragen. It can be seen from the result of t-test on learning activity and output. The Jigsaw method effect on learning activity and output give medium effect. This means, Jigsaw method was efective on students' learning activity and output in IPS learning at SMP Negeri 1 Masaran Sragen Grade VIII. Learning using the Jigsaw method makes active learners who create cooperation that can increase student involvement by doing their own activities. Cooperative learning gives students the opportunity to develop or create ideas that can be learned by students themselves which ultimately increase student knowledge compared to if students only listen to the explanation from the teacher.

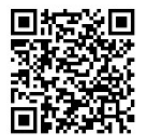

This is an open access article under the CC-BY-SA license. 


\section{PENDAHULUAN}

Pendidikan merupakan aspek penting bagi pengembangan sumber daya manusia. Pendidikan menjadi salah satu instrumen yang dapat digunakan untuk membebaskan manusia dari keterbelakangan, melainkan juga dari kebodohan atau kemiskinan. Pendidikan juga mampu menanamkan kapasitas baru bagi semua orang untuk mempelajari pengetahuan dan keterampilan sehingga dapat diperoleh manusia yang produktif. Dunia pendidikan erat kaitannya dengan bagaimana usaha untuk meningkatkan proses belajar mengajar sehingga memperoleh hasil yang efektif dan efisien. Proses belajar mengajar merupakan kegiatan yang sangat penting dalam pendidikan karena tercapainya tujuan pendidikan diawali dari proses belajar mengajar. Proses belajar mengajar merupakan proses komunikasi yang di dalamnya terdapat berbagai kegiatan, salah satu diantaranya yaitu penyampaian materi pelajaran. Kemampuan guru dalam menyampaikan materi pelajaran memiliki andil yang besar dalam mencapai tujuan pendidikan yang telah ditetapkan. Guru sebagai penyelenggara kegiatan belajar harus mampu mengoptimalkan kegaiatan belajar mengajar. Salah satu cara yang dapat digunakan untuk mengoptimalkan kegiatan pembelajaran yaitu dengan penggunaan metode pembelajaran yang tepat, tetapi masih banyak guru yang belum mengoptimalkan metode pembelajaran yang tepat dalam menyampaikan materi pelajaran di kelas.

Asih (2015, p.1) menyebutkan bahwa masih terdapat kecenderungan guru dalam pembelajaran IPS menggunakan cara konvensional atau tradisional, sehingga pembelajaran tidak berpusat pada siswa. Minimnya penggunaan metode pembelajaran membuat kegiatan belajar mengajar kurang efektif dan menarik. Metode ceramah yang biasa digunakan oleh guru dalam kegiatan belajar mengajar sering dianggap membosankan oleh siswa dan aktivitas belajar siswa menjadi rendah. Hal ini dapat dilihat dari banyaknya siswa yang mengobrol dengan teman sebangkunya ketika guru sedang menyampaikan materi pelajaran. Penggunaan metode yang bekerja secara individu, misalnya metode ceramah membuat kurangnya keterlibatan atau aktivitas siswa dalam kegiatan belajar. Banyak siswa yang mengantuk dan tidak memperhatikan saat guru menyampaikan materi pelajaran, kurangnya keberanian siswa dalam mengemukakan ide dan pendapat, sedikit yang aktif bertanya ketika diberi kesempatan oleh guru untuk menanyakan materi pelajaran yang kurang jelas. Ketika guru mulai mengajak diskusi mengenai materi pelajaran, terlihat siswa kurang antusias. Hal ini sesuai dengan penelitian yang dilakukan oleh Pollio (Silberman, 2013, p.24) yang menunjukkan bahwa dalam pembelajaran dengan metode ceramah, siswa kurang menaruh perhatian selama $40 \%$ dari seluruh waktu pembelajaran.

Realitas yang terjadi di kelas VIII SMP Negeri 1 Masaran berdasarkan observasi sebelum penelitian, terlihat bahwa masih ada beberapa siswa kurang bersemangat dan kurang terlibat pada saat pembelajaran IPS berlangsung. Walaupun guru sudah menggunakan berbagai media pembelajaran yang menarik seperti slide powerpoint, video, dan gambar, akan tetapi interaksi pembelajaran yang terjadi tetap satu arah. Siswa hanya antusias saat menonton video atau film yang diputar. Setelah itu siswa tetap cenderung pasif dan tidak memiliki keberanian bertanya maupun mengemukakan pendapat di depan guru dan siswa yang lain. Kurang terlibatnya siswa dalam mengikuti kegiatan pembelajaran tentu akan berpengaruh pada pemahaman materi yang tidak maksimal, sehingga hasil belajar yang diperoleh juga kurang maksimal. Pola pembelajaran yang bersifat guru sentris atau pembelajaran yang berpusat pada guru dan metode pembelajaran yang masih konvensional membuat siswa kurang dilibatkan dalam proses belajar mengajar dan siswa cenderung pasif. Kecenderungan pembelajaran tersebut mengakibatkan lemahnya pengembangan potensi diri siswa kurang optimal (Wilujeng, 2015, p. 115). Siswa hanya menerima atau mengandalkan materi yang dijelaskan oleh guru. Peran aktif siswa sangat diperlukan dalam proses pembelajaran IPS. Peran aktif siswa dapat membantu dan memudahkan siswa dalam memahami materi pelajaran. Siswa juga dapat mengembangkan potensi yang dimilikinya sehingga mampu mencapai hasil belajar IPS yang optimal. Langkah kooperatif, variatif dan inovatif yang dilakukan guru dalam proses pembelajaran dapat mendorong peran aktif siswa. Siswa dapat mencari pengalaman atau pengetahuan baru sehingga siswa dapat mengembangkan kemampuan di dalam dirinya secara optimal.

Pemilihan metode pembelajaran merupakan hal yang sangat penting untuk diperhatikan karena metode merupakan salah satu alat untuk mencapai tujuan pembelajaran. Memanfaatkan suatu 
metode secara akurat, dapat membantu guru dalam mencapai tujuan pembelajaran. Penggunaan metode pembelajaran yang tepat dalam proses belajar mengajar, diharapkan pembelajaran menjadi lebih efektif. Pembelajaran yang efektif akan melatih dan menanamkan sikap demokratis bagi siswa serta menekankan siswa mampu belajar secara mandiri. Penerapan metode pembelajaran yang tepat merupakan solusi supaya aktivitas belajar mengajar menjadi menyenangkan dan mencapai efektivitas. Pendekatan pembelajaran yang dapat dilakukan adalah pembelajaran aktif, yaitu dengan model pembelajaran kooperatif. "Cooprative Learning is defined as an interactive learning teaching method based on studying of students as small groups in cooperation, in order to realize the shared learning aims at the maximum level" Johnson et al (Er, 2017, p. 838). Pembelajaran kooperatif didefinisikan sebagai metode pembelajaran interaktif berbasi pembelajaran siswa sebagai kelompok kecil dalam kerjasama, untuk mewujudkan pembelajaran bersama yang bertujuan pada tingkat maksimum. Cooperative learning memberi kesempatan siswa untuk mengembangkan atau menciptakan ide-ide yang dapat dipelajari sendiri atau dengan kerjasama kelompok yang akhirnya menambah pengetahuan siswa dibandingkan jika siswa hanya mendengarkan penjelasan dari guru.

Metode pembelajaran kooperatif atau cooperative learning yang dapat diterapkan dalam kegiatan pembelajaran salah satunya yaitu Jigsaw. Metode Jigsaw merupakan suatu metode yang dikembangkan oleh Slavin, di dalam metode Jigsaw ada hubungan saling ketergantungan positif antar siswa, ada tanggung jawab perseorangan, serta ada komunikasi antar anggota kelompok. Komunikasi yang terjadi di dalam kelompok diharapkan mampu membuat anggota kelompok mengerti dan memahami materi yang didiskusikan bersama. Penggunaan metode Jigsaw bertujuan untuk membuat siswa aktif di dalam kelas dan tidak mudah jenuh dalam menerima materi pelajaran, karena adanya interaksi sosial antara siswa dengan bekerjasama dalam kelompok. Berdasarkan uraian di atas, maka peneliti tertarik untuk melakukan penelitian eksperimen berjudul "Efektivitas Pembelajaran Metode Jigsaw Terhadap Aktivitas dan Hasil Belajar dalam Pembelajaran IPS Siswa Kelas VIII SMP Negeri 1 Masaran Sragen".

\section{Efektivitas Pembelajaran}

Adesoji (Ataman \& Emine Hatun D, 2017, p. 86) juga mengungkapkan bahwa: The effectiveness of teaching and learning process can be facilitated through appropriate strategies adopted in a learning environement. Classroom environment can be charactrized with various thougth patterns of learners. These differences stem from the differences in the information processing mechanisms of individuals. Although teachers can do nothing for their learners to expand their mental capacities, teachers can change their teaching strategies to facilitate their learners' understanding of the concepts. Pendapat tersebut memberi makna bahwa efektivitas proses belajar mengajar dapat difasilitasi melalui strategi yang tepat diadopsi dalam lingkungan belajar. Lingkungan kelas bisa dicirikan dengan berbagai pola pikir siswa. Perbedaan ini berasal dari perbedaan mekanisme pengolahan informasi individu, meskipun guru tidak bisa berbuat apa-apa untuk para siswa guna memperluas kapasitas mental mereka, guru dapat mengubah strategi pengajaran untuk memfasilitasi para siswa memahami konsep.

Efektivitas pembelajaran dalam interaksi belajar mengajar merupakan segala daya upaya yang dilakukan oleh guru agar siswa dapat belajar dengan baik. Efektivitas guru mengajar dapat dilihat dari keberhasilan yang dicapai siswa dalam menguasai materi yang disampaikan. Pendapat ini didukung oleh Soekartawi (1995, p. 66) bahwa pembelajaran dinilai efektif ketika aktivitas belajar siswa meningkat. Ellis (Soewandi, Widharyanto, Bram, Nugraha, \& Nugroho, 2008, p. 43-44) menambahkan efektivitas selain mengacu pada proses, juga mengacu pada hasil. Efektivitas mengacu pada proses yakni dilihat dari keterlibatan siswa dalam proses pembelajaran, sedangkan mengacu pada hasil dilihat prestasi akademik yang dicapai melalui tes. Beberapa definisi mengenai efektivitas yang telah dijelaskan, peneliti mengacu kepada pendapat Ellis (Soewandi et al., 2008, p.43-44), karena peneliti menganggap pendapat tersebut yang paling tepat bahwa efektivitas pembelajaran dalam interaksi belajar mengajar merupakan segala daya upaya yang dilakukan oleh guru agar siswa dapat belajar dengan baik. Pembelajaran dinilai efektif ketika aktivitas belajar siswa meningkat. Efektivitas selain mengacu pada proses, juga mengacu pada hasil. Efektivitas mengacu pada proses yakni dilihat dari keterlibatan siswa dalam proses pembelajaran, sedangkan mengacu 
pada hasil dilihat prestasi akademik yang dicapai melalui tes, sehingga dalam hal ini efektivitas pembelajaran dapat dilihat dari aktivitas dan hasil belajar.

Ilmu Pengetahuan Sosial

Singer (2009, p. 18) menegaskan bahwa “...social studies has to be organized into curricula with calendars, units, and lessons that include goals, content, and concepts that 1.) Promote academic and social skills; 2.) Raise questions; 3.) Provoke disagreements; and 4.) Stimulate action." Pendapat tersebut mengungkapkan bawah IPS telah diatur dalam kurikulum dengan kalender, unit, dan pelajaran yang termasuk tujuan, konten, dan konsep yang 1.) Mempromosikan ketrampilan sosial dan akademis; 2.) Meningkatkan kualitas pertanyaan; 3.) Menyampaikan perbedaan pendapat; 4.) Melihat isu-isu kontroversial; 5.) Mencari koneksi; dan 6.) Simulasi tindakan. IPS mengedepankan peristiwa yang terjadi dalam kehidupan sehari-hari untuk kemudian disesuaikan dengan materi pembelajaran dan dikaji menurut disiplin keilmuan.

Supardi (2011, p. 182) mengemukakan bahwa IPS merupakan kajian integrasi berbagai ilmu sosial dan humaniora. IPS didesain secara terpadu agar pembelajaran IPS menjadi lebih bermakna. Keterpaduan dalam IPS juga bertujuan agar siswa mampu menelaah masalah sosial karena manusia selalu dihadapkan dengan fenomena ataupun masalah sosial. Trianto (2012, p. 171) berpendapat bahwa Ilmu Pengetahuan Sosial (IPS) merupakan integrasi dari berbagai cabang ilmuilmu sosial, seperti sosiologi, sejarah, geografi, ekonomi, politik, hukum dan budaya. Berdasarkan beberapa definisi mengenai Ilmu Pengetahuan Sosial di atas, peneliti memilih pendapat dari Supardi yang menyatakan bahwa pembalajaran IPS merupakan pembelajaran yang terdiri dari beberapa disiplin ilmu yang dirumuskan berdasarkan fenomena sosial di lingkungan masyarakat. Pembelajaran IPS yang diberikan kepada siswa diharapkan mampu memberikan keterampilan kepada peserta didik dalam memecahkan masalah-masalah sosial yang ada di lingkungan masyarakat. Pembelajaran IPS juga diharapkan dapat memperbaiki moral serta membentuk karakter siswa menjadi lebih baik sehingga siswa dapat memecahkan masalah-masalah sosial dengan bijak.

Metode Jigsaw

Donald dan Eggen (1940, p. 394) menyatakan bahwa "In the jigsaw strategy, students on a team are responsible for learning on integrated body of knowledge; each student on a team is assigned one component of the larger body. Each student is then responsible for teaching that part of to others (just the name jigsaw). In contrast with group investigations that begin with a problem, jigsaw activities begin with a topic that can be subvided into smaller subtopics...". pendapat tersebut memberi makna bahwa metode jigsaw mengarahkan siswa bertanggung jawab untuk mempelajari pengetahuan secara menyeluruh dalam kelompok. Setiap siswa dalam kelompok ditugaskan mempelajari salah satu dari komponen yang luas. Setiap siswa bertanggung jawab untuk mengajarkan materi yang dipelajarinya kepada anggota lain. Berbeda dengan kelompok investigasi yang memulai dengan masalah, aktivitas jigsaw dimulai dengan topik yang terbagi dalam subtopik yang lebih kecil. Metode pembelajaran kooperatif tipe jigsaw merupakan metode pembelajaran kooperatif, dengan siswa belajar dalam kelompok-kelompok kecil yang terdiri dari 4-6 orang secara heterogen dan bekerjasama saling ketergantungan yang positif dan bertanggung jawab atas ketuntasan bagian materi pelajaran yang harus dipelajari dan menyampaikan materi tersebut kepada anggota kelompok yang lain (Arends, 1997, p. 37).

Singh (Dollard \& Mahoney: 2010) yang menambahkan bahwa "The Jigsaw Method in an effective way to create a feeling of equality among students. Prejudice may be reduced by equal status contact between majority and minority studnets in the pursuit of common goals". Metode jigsaw adalah cara efektif untuk menciptakan kesetaraan di antara siswa. Prasangka dapat dikurangi dngan kontak status yang sama antara mayoritas dan minoritas dalam mengejar tujuan bersama. Berdasarkan beberapa pendapat di atas, peneliti mengacu kepada pendapat (Arends, 1997, p. 37) bahwa metode Jigsaw merupakan metode pembelajaran dengan siswa belajar dalam kelompokkelompok kecil yang terdiri dari 4-6 orang, heterogen dan bekerjasama saling membantu. Setiap anggota kelompok bertanggung jawab atas ketuntasan bagian bahan pelajaran yang mesti dipelajari dan menyampaikan bahan tersebut kepada anggota kelompok asal. Setiap kelompok mendapat tagihan laporan diskusi kelompok dan dipresentasikan di depan kelas. 


\section{Metode Ceramah}

Hasibuan (2004, p. 13) menjelaskan bahwa metode ceramah adalah cara penyampaian bahan pelajaran dengan komunikasi lisan. Metode ceramah ekonomis dan efektif untuk keperluan penyampaian informasi dan pengertian. Seringkali guru mengandalkan metode ceramah karena memiliki keterbatasan waktu mengajar dan masih banyak materi pelajaran yang belum disampaikan. Mengenai hal tersebut Djamarah dan Zain (2013, p. 97), mengemukakan bahwa metode ceramah adalah cara penyajian pelajaran yang dilakukan guru dengan penuturan atau penjelasan lisan secara langsung terhadap siswa. Ardalan dan College (2013, p. 2) juga menambahkan bahwa "in the lecture method, the educational process is devoted to applying rigorously-defined methods to questions or problems carrefully posed by others in order to find answers". Pendapat tersebut memberi arti bahwa dalam metode ceramah, proses pendidikan dikhususkan untuk menerapkan metode yang didefinisikan secara ketat mengenai pertanyaan atau masalah yang diajukan dengan hati-hati oleh orang lain agar bisa menemukan jawaban. Menanggapi hal tersebut, metode ceramah tidak boleh dianggap remeh. Guru dalam menyampaikan materi pelajaran harus benar-benar menguasai. Sehingga mampu memberikan jawaban secara tepat kepada siswa.

Sagala (2009, p. 201) mengatakan bahwa ceramah dikatakan sebagai kegiatan memberikan informasi dengan kata-kata yang sering mengaburkan dan kadang-kadang ditafsirkan salah. Senada dengan hal tersebut Mohammadjani \& Tokaboni (2015, p. 107) juga berpendapat bahwa "Traditional methods consider classrooms as places where the role of teachers is merely to provide information to their students. Students work individually or comptitively. In this method, students are practically trying to increase their knowledge. In such classes, goals are personal which contradicts with cooperative classes". Pendapat tersebut dapat diartikan bahwa metode ceramah menganggap ruang kelas sebagai tempat dimana peran guru semata-mata memberikan informasi kepada siswa. Siswa bekerja secara individu atau dengan cara bersaing. Di kelas seperti ini, tujuan bersifat pribadi yang bertentangan dengan kerjasama. Beberapa pendapat mengenai metode ceramah, peneliti memilih pendapat Hasibuan, karena peneliti menganggap pendapat tersebut yang paling tepat bahwa metode ceramah merupakan cara penyampaian bahan pelajaran dengan komunikasi lisan. Metode ceramah ekonomis dan efektif untuk keperluan penyampaian informasi dan pengertian.

\section{Aktivitas Belajar}

Aktivitas belajar siswa merupakan salah satu faktor penting dalam kegiatan pembelajaran. Hal ini mengingat bahwa kegiatan pembelajaran diadakan dalam rangka memberikan pengalamanpengalaman belajar pada siswa. Pengalaman-pengalaman belajar tersebut didapat ketika siswa dilibatkan dalam pembelajaran. Gurvitch (2013, p. 32) menjelaskan bahwa "Learning activities are defined as the way students are enganged with the content for the purpose of learning, it is important to establish a match between the selected model and the learning activities". Pendapat tersebut mengungkapkan bahwa Aktivitas belajar didefinisikan sebaga cara siswa terlibat dengan konten untuk tujuan belajar, itu penting untuk membuat kecocokan antara model yang dipilih dan kegiatan belajar. Sardiman (2010, p. 100) menjelaskan bahwa aktivitas belajar adalah aktivitas yang bersifat fisik maupun mental dan dalam kegiatan belajar ke dua aktivitas itu harus saling berkaitan. Aktivitas mental berkaitan dengan kemampuan siswa dalam mengidentifikasi masalah, membandingkan dan menganalisis materi yang disampaikan oleh guru. Aktivitas fisik misalnya melakukan gerakan badan atau anggota badan lainnya seperti tangan dan kaki untuk melakukan ketrampilan. Aktivitas belajar dalam arti luas yang bersifat fisik maupun mental dapat menumbuhkan aktivitas belajar yang optimal.

Hamalik (2011, p. 89), mendefinisikan aktivitas belajar sebagai berbagai aktivitas yang diberikan pada pembelajar dalam situasi belajar mengajar. Aktivitas belajar ini didesain agar memungkinkan siswa memperoleh muatan yang ditentukan, sehingga berbagai tujuan yang ditetapkan terutama maksud dan tujuan kurikulum dapat terjadi. Guru akan berperan sebagai fasilitator yang memfasilitasi serta mendorong siswa agar bekerja sendiri sehingga aktif dalam kegiatan pembelajaran. Beberapa pendapat para ahli mengenai aktivitas belajar yang telah dijelaskan, peneliti memilih pendapat Sardiman karena peneliti menganggap pendapat tersebut yang paling tepat bahwa aktivitas belajar merupakan aktivitas yang bersifat fisik maupun mental yang dilakukan siswa 
selama proses pembelajaran berlangsung. Aktivitas mental misalnya meng-identifikasi masalah, membandingkan dan menganalisis, sedangkan aktivitas fisik seperti melakukan gerakan badan.

Hasil Belajar

Hasil belajar merupakan salah satu hal yang penting dalam kegiatan pembelajaran. Hasil belajar digunakan untuk mengetahui sejauh mana siswa memahami materi pelalajaran. Menurut London Communique (Elmgren, Ho, Akesson, Schmid, \& Towns, 2015, p. 1) mengemukakan bahwa "Learning outcomes place the focus on the student and his or her learning, rather than on the teacher and hir or her learning, rather then on the teacher and the content of the course". Hasil belajar menempatkan fokus pada siswa dan belajarnya, bukan pada guru dan isi pelajaran. Hal ini disarankan untuk mendesain pembelajaran yang berpusat pada siswa sehingga siswa menjadi lebih aktif. Sudjana (2012, p. 22), hasil belajar adalah kemampuan-kemampuan yang dimiliki siswa setelah ia menerima pengalaman belajarnya. Berkaitan dengan hal itu, Proitz (Molstad \& Karseth 2016, pp. 329-330) juga mengemukakan bahwa "Learning outcomes can be described as what pupils or students can actually do with what they know and have learned". Hasil belajar dapat digambarkan tentang apakah siswa benar-benar dapat melakukan dengan apa yang telah mereka ketahui dan pelajari. Sehubungan dengan definisi hasil belajar yang telah diungkapkan Proitz dalam jurnal yang sama (Melton, 1996; Spady, 1994) juga mengemukakan pendapat bahwa outcomes are actions and performances that contain and reflect the learner's competence in succesfully using content, information, ideas and tools. Define learning outcomes as the copetence and skills will have after a period of learning. Hasil adalah tindakan dan pertunjukan yang mengandung dan mencerminkan kompetensi siswa berhasil menggunakan isi, informasi, gagasan dan alat. Definisi hasil belajar sebagai kompetensi dan ketrampilan yang dimiliki siswa setelah proses pembelajaran.

Beberapa pendapat mengenai hasil belajar tersebut, peneliti memilih pendapat Sudjana karena peneliti menganggap pendapat tersebut paling tepat bahwa hasil belajar adalah kemampuankemampuan yang dimiliki siswa setelah ia menerima pengalaman belajarnya. Hasil belajar dalam penelitian ini menggunakan hasil belajar secara kognitif berupa tes pilihan ganda. Tes pilihan ganda terdiri atas suatu pemberitahuan tentang pengertian yang belum lengkap dan untuk melengkapinya harus memilih salah satu dari beberapa kemungkinan jawaban yang telah disediakan. Tes dilakukan sebanyak dua kali yaitu berupa pretest dan posttest. Tujuan pretest yaitu untuk mengetahui hasil kemampuan awal siswa sebelum diberi perlakuan. Sedangkan tujuan dari posttest yaitu untuk mengetahui hasil kemampuan siswa setelah diberi perlakuan. Peningkatan hasil belajar dapat diketahui dari skor pretest dan posttest

\section{METODE}

Desain Penelitian

Jenis Penelitian ini menggunakan True Eksperimental Design. Peneliti menggunakan desain penelitian yang berbentuk pretest-posttest control group design menggunakan satu jenis perlakuan Bagan desain penelitian yang digunakan dalam penelitian (Sugiyono, 2010, p. 114) dapat dilihat pada Tabel 1.

Tabel 1. Desain Penelitian

\begin{tabular}{cccc}
\hline Grup & Pretest & Variabel Bebas (X) & Posttest \\
\hline $\mathrm{KE}$ & $Y_{1}$ & $\mathrm{X}$ & $Y_{2}$ \\
$\mathrm{KK}$ & $Y_{1}$ & - & $Y_{2}$ \\
\hline
\end{tabular}

\footnotetext{
Keterangan:

$\mathrm{KE}=$ Kelompok Eksperimen

$\mathrm{KK}=$ Kelompok Kontrol

$\mathrm{X}=$ Perlakuan dengan Metode Jigsaw

- $\quad=$ Perlakuan dengan Model Diskusi

$Y_{1} \quad=$ Pretest dan angket 1

$Y_{2}=$ Posttest dan angket
} 
Tempat dan Waktu Penelitian

Tempat penelitian ini dilaksanakan di SMP Negeri 1 Masaran, yang beralamat di Jalan Raya Masaran-Sragen Km.11, Jati, Kecamatan Masaran, Kabupaten Sragen. Waktu penelitian ini dilaksanakan pada bulan Mei - Juni 2017. Penelitian ini baik pada kelas eksperimen maupun kelas kontrol dilaksanakan dengan alokasi waktu 80 menit untuk setiap pertemuan.

Populasi dan Sampel Penelitian

Populasi dalam penelitian ini adalah semua kelas VIII SMP Negeri 1 Masaran Sragen tahun ajaran 2016/2017. Rincian data kelas VIII dapat dilihat Tabel 2.

Tabel 2. Populasi Penelitian

\begin{tabular}{cc}
\hline Kelas & Jumlah \\
\hline VIII A & 32 Siswa \\
VIII B & 32 Siswa \\
VIII C & 32 Siswa \\
VIII D & 32 Siswa \\
VIII E & 32 Siswa \\
VIII F & 32 Siswa \\
VIII G & 32 Siswa \\
VIII H & 32 Siswa \\
Total & 256 Siswa \\
\hline
\end{tabular}

Pengambilan sampel dalam penelitian ini menggunakan teknik purposive sampling, yaitu sampel diambil dengan melihat karakteristik siswa. Penelitian ini diambil dua kelas dengan tingkat aktivitas dan hasil belajar yang sama rendahnya. Peneliti berkonsultasi dengan Guru Mata Pelajaran IPS, untuk menentukan kedua kelas sampel. Nilai hasil ujian semester 1 mata pelajaran IPS juga digunakan sebagai pertimbangan dalam menentukan kedua kelas tersebut, kemudian dari dua kelas sampel ditentukan kelas yang berfungsi sebagai kelas eksperimen dan kelas kontrol. Penentuan kelas eksperimen dan kontrol dilakukan dengan cara diundi sehingga terpilih kelas VIII D sebagai kelas eksperimen dan kelas VIII C sebagai kelas kontrol.

\section{Teknik Pengumpulan Data}

Teknik pengumpulan data yang digunakan oleh peneliti dalam penelitian ini adalah dengan menggunakan: a.) Observasi, peneliti menggunakan teknik observasi untuk memperoleh data pelaksanaan metode Jigsaw, metode Ceramah dan aktivitas belajar. Pelaksanaan observasi mengacu pada pedoman observasi yang telah didesain peneliti dalam bentuk lembar observasi; b.) Angket, teknik pengambilan data menggunakan angket dilakukan oleh peneliti untuk mengukur aktivitas belajar pada kelas eksperimen dan kelas kontrol. Pemberian angket dilakukan sebelum dan sesudah diberi perlakuan; dan c.) Tes, teknik pengumpulan data dengan tes digunakan untuk mengukur tingkat pemahaman siswa terhadap materi yang diajarkan. Tes berupa soal diberikan sebelum dan sesudah pemberian perlakuan berupa metode Jigsaw dan metode ceramah pada kedua kelas tersebut. Aktivitas belajar jika mengalami peningkatan, berpengaruh pula pada hasil tes siswa. Tes ini berbentuk tes obyektif yang berupa serangkaian pertanyaan yang terdiri empat opsi jawaban yaitu a, b, c, dan d. Pengisian dapat dilakukan dengan cara memberikan tanda silang pada salah satu jawaban yang dianggap tepat. Tes diberikan sebelum dan sesudah pemberian perlakuan.

\section{Instrumen Penelitian}

Instrumen penelitian yang digunakan dalam penelitian ini adalah: a.) Lembar observasi, peneliti melakukan pengambilan data mengenai pelaksanaan metode Jigsaw, metode ceramah dan aktivitas belajar melalui lembar observasi. Lembar observasi dibuat dengan menggunakan panduan 
kisi-kisi intrumen penelitian; b.) Lembar angket, peneliti memberikan angket tertutup kepada siswa untuk mengetahui aktivitas dalam pembelajaran IPS; dan c.) Tes, tes yang digunakan dalam penelitian ini berupa soal pilihan ganda yang terdiri atas empat alternatif pilihan $a, b, c$ dan $d$. Keempat alternatif pilihan jawaban tersebut hanya ada satu jawaban yang benar. Skor tiap soalnya 1 untuk jawaban benar dan 0 untuk jawaban yang salah.

\section{Uji Coba Instrumen Penelitian}

Instrumen penelitian yang telah disusun harus diuji validitas dan reliabilitasnya sebelum digunakan. Pengujian ini dilakukan untuk mengetahui kelayakan instrumen yang akan digunakan dalam penelitian.

\section{Uji Validitas}

Validitas merupakan suatu ukuran yang menunjukkan tingkatan-tingkatan kevalidan atau kesahihan instrumen. Instrumen dalam penelitian ini mempergunakan validitas logis. Validitas logis pada prinsipnya mencakup validitas isi dan konstruk yang ditentukan utamanya atas dasar pertimbangan dosen pembimbing dan narasumber sebelum instrumen diujicobakan. Perhitungan validitas dalam sebuah instrumen dapat menggunakan rumus korelasi product moment atau dikenal dengan pearson. Adapun rumusnya dapat dilihat pada Rumus 1.

Keterangan:

$$
r_{x y}=\frac{\mathrm{N} \sum \mathrm{XY}-\left(\sum \mathrm{X}\right)\left(\sum \mathrm{Y}\right)}{\left.\sqrt{\mathrm{N} \sum \mathrm{X}^{2}}-\left(\sum \mathrm{X}\right)^{2}\right)\left(\mathrm{N} \sum \mathrm{Y}^{2}-\left(\sum \mathrm{Y}\right)^{2}\right)}
$$

$r_{x y}=$ koefisien korelasi

$\mathrm{N}=$ jumlah responden

$\mathrm{X}=$ jumlah responden uji coba

$\mathrm{X}=$ skor tiap item

$\mathrm{Y} \quad=$ skor seluruh item responden uji coba

\section{Uji Reliabilitas}

Reliabilitas adalah derajat konsisten instrumen yang bersangkutan. Instrumen dapat dikatakan reliabel jika selalu memberikan hasil yang sama jika diujikan pada kelompok yang sama pada waktu yang berbeda. Pengujian reliabilitas menggunakan metode belah dua (Split Half Method) yang dianalisis dengan rumus Spearman Brown. Untuk mengujinya dibantu dengan Program SPSS 16.00 for windows dengan taraf signifikan 0,05. Instrumen dinyatakan reliabel jika koefisien korelasinya $\geq 0,6$. Semakin tinggi koefisien korelasinya semakin reliabel instrumen tersebut, dan sebaliknya. Rumus yang digunakan peneliti untuk menguji reliabiltas instrumendapat dilihat pada Rumus 2.

$$
r_{i}=\frac{2 \cdot r_{b}}{1+r_{b}}
$$

Keterangan:

Sumber: (Sugiyono, 2010, p.190)

$r_{i}=$ reliabilitas instrument

$r_{b}=$ koefisien relasi

Teknik Analisis Data

\section{Uji Prasyarat Analisis}

Teknik analisis data yang digunakan peneliti dalam penelitian ini yaitu uji prasyarat analisis. Data yang diperoleh bisa dianalisis menggunakan uji-t jika data tersebut berdistribusi normal dan homogen. Untuk itu perlu adanya uji normalitas dan homogenitas data.

\section{a. Uji Normalitas}

Data tes dan angket perlu diuji untuk megetahui kondisi data tersebut berdistribusi normal atau tidak. Pengujian normalitas menggunakan uji Kolmogorov Smirnov. Untuk mengujinya dibantu 
dengan program SPSS 16.00 for Windows. Data dikatakan normal apabila mempunyai nilai signifikansi lebih dari 0,05 atau grafik berbentuk lonceng.

$$
D=\text { maksimum } \mid F_{0}(X)-S_{N}(X)
$$

Keterangan:

$$
\begin{array}{ll}
F_{0} & =\begin{array}{l}
\text { Suatu fungsi distribusi frekuensi kumulatif yang sepenuhnya ditentukan, yakni distribusi } \\
\text { kumulatif teoritis di bawah } \mathrm{H}_{0}
\end{array} \\
S_{N}(X)= & \text { distribusi frekuensi kumulatif yang diobservasi dari suatu sampel random dengan } N \text { observasi }
\end{array}
$$

b. Uji Homogenitas

Pengujian ini bertujuan untuk mengetahui kesamaan (homogenitas) seragam atau tidaknya sampel-sampel yang diambil dari populasi yang sama. Apabila varians yang dimiliki sampel-sampel yang bersangkutan tidak jauh berbeda maka sampel-sampel tersebut cukup homogen. Pengujian homogenitas menggunakan metode Levene Test, untuk mengujinya dibantu dengan program SPSS 16.00 for Windows dengan signifikan 0,05 . Kriteria pengujiannya jika nilai signifikansinya lebih dari 0,05 , maka dapat dikatakan bahwa varian dari kelompok data adalah sama (homogen), tetapi jika nilai signifikansinya kurang dari 0,05 , maka varian dari kelompok data adalah tidak sama (tidak homogen). Untuk itu apabila tidak homogen, pengujian hipotesis yang digunakan adalah dengan menggunakan tes U Man-Whitney (Purwanto, 2011, p. 149). Rumus yang digunakan peneliti untuk menguji homogenitas data dapat dilihat pada Rumus 4.

$$
F_{\text {hitung }}=\frac{\text { varian terbesar }}{\text { varian terkecil }}
$$

Sumber: (Riduwan, 2011, p.120)

Keterangan:

$F \quad=$ koefisien homogenitas sampel

Uji Hipotesis

Teknik analisis yang digunakan untuk menguji hipotesis dalam penelitian ini yaitu uji-t. Uji$t$ ini bertujuan untuk mengetahui perbedaan hasil belajar yang signifikan antara pembelajaran IPS dengan metode Jigsaw dengan metode ceramah dalam pembelajaran IPS. Untuk mengujinya dibantu dengan Program SPSS 16.00 for Windows dengan taraf signifikan 0,05. Kriteria pengujiannya dalam Riduwan (2012, p.166) jika $t_{\text {hitun }} \geq t_{\text {tabel }}$, maka Ho ditolak dan Ha diterima. Rumus yang digunakan peneliti untuk menguji hipotesis data dapat dilihat pada Rumus 5.

$$
t=\frac{\bar{x}_{1}-\bar{x}_{2}}{\sqrt{\frac{S_{1}^{2}}{n_{1}}+\frac{S_{2}^{2}}{n_{2}}-2 r\left(\frac{S_{1}}{\sqrt{n_{1}}}\right)\left(\frac{S_{2}}{\sqrt{n_{2}}}\right)}}
$$

Sumber: (Sugiyono, 2009, p.197)

\section{Keterangan:}

$\bar{X}_{1}=$ Nilai rerata kelas eksperimen

$\bar{X}_{2}=$ Nilai rerata kelas kontrol

$s_{1}^{2}=$ Varian kelas eksperimen

$s_{2}^{2}=$ Varian kelas kontrol

$n_{1}=$ Jumlah anggota kelas eksperimen

$n_{2}=$ Jumlah anggota kelas kontrol

$t \quad=$ nilai $t$ yang dihitung 


\section{Ukuran Efek}

Setelah dilakukan pengujian hipotesis, maka dilakukan pengukuran efektivitas metode Jigsaw untuk meningkatkan aktivitas dan hasil belajar IPS siswa kelas VIII SMP Negeri 1 Masaran Sragen. Pengukuran efktivitas dapat dilakukan dengan rumus Cohen D yang dapat dilihat pada Rumus 6.

$$
\text { Ukuran efek Cohen } \mathrm{D}=\frac{\text { selis } \text { rerata }}{\text { simpangan baku }}
$$

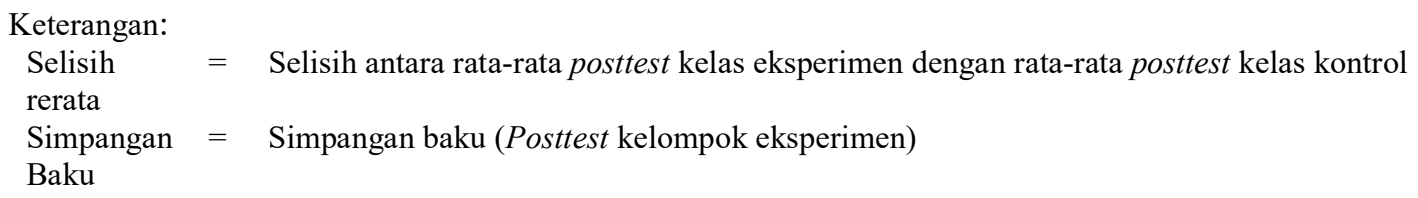

Kriteria yang diusulkan oleh Cohen tentang besar kecilnya ukuran efek adalah bahwa apabila $0<\mathrm{d}<0,2$, maka efek kecil (selisih rerata kurang dari 0,2 simpangan baku), apabila $0,2<\mathrm{d}$ $<0,8$, maka efek sedang (selisih rerata sekitar 0,5 simpangan baku), sedangkan apabila $\mathrm{d}>0,8$, maka efek besar (selisih rerata lebih dari 0,8 simpangan baku) (Naga, 2009, p. 99).

\section{HASIL DAN PEMBAHASAN}

Hasil penelitian perbandingan Data Kelas Eksperimen dengan Kelas Kontrol disajikan sebagai berikut.

\section{Perbandingan Peningkatan Hasil Angket Aktivitas Belajar Siswa}

Data angket aktivitas belajar awal dan akhir siswa yang diperoleh untuk kelas eksperimen dan kelas kontrol, dapat dijadikan acuan guna hasil peningkatan aktivitas belajar IPS untuk masingmasing kelas tersebut dapat dilihat pada Tabel 3.

Tabel 3. Peningkatan Hasil Angket Aktivitas Belajar

\begin{tabular}{lccc}
\hline \multirow{2}{*}{ Kelas } & \multicolumn{2}{c}{ Mean Hasil Pencapaian } & \multirow{2}{*}{ Peningkatan } \\
& Awal & Akhir & 7,3437 \\
Eksperimen & 64,0313 & 71,3750 & 3,1563 \\
Kontrol & 63,7500 & 66,9063 & \\
\hline
\end{tabular}

Data peningkatan aktivitas belajar IPS siswa melalui angket menunjukkan bahwa kelas eksperimen lebih tinggi peningkatannya dibandingkan kelas kontrol. Lebih jelasnya dapat dilihat pada Gambar 1.

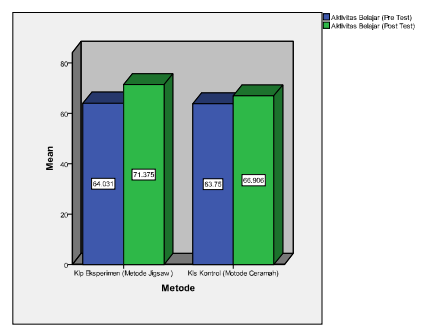

Gambar 1. Diagram Perbandingan Peningkatan Hasil Angket Aktivitas Belajar Siswa

\section{Perbandingan Hasil Belajar Pretest dan Posttest}

Data hasil belajar awal dan akhir siswa yang diperoleh untuk kelas eksperimen dan kelas kontrol, dapat dijadikan acuan guna hasil peningkatan hasil belajar IPS untuk masing-masing kelas tersebut dapat dilihat pada Tabel 4. Perhitungan tersebut dapat diketahui bahwa kelas eksperimen 
mempunyai rata-rata nilai hasil belajar yang lebih tinggi dibandingkan dengan kelas kontrol. Lebih jelasnya dapat dilihat pada Gambar 2.

Tabel 4. Rata-rata Nilai Kelas Eksperimen dan Kontrol

\begin{tabular}{ccc}
\hline Sumber & Kelas Eksperimen (Jigsaw) & Kelas Kontrol (Ceramah) \\
\hline Pretest & 69,5313 & 67,0313 \\
Posttest & 80,0000 & 72,0313 \\
Peningkatan & 10,4687 & 5,0000 \\
\hline
\end{tabular}

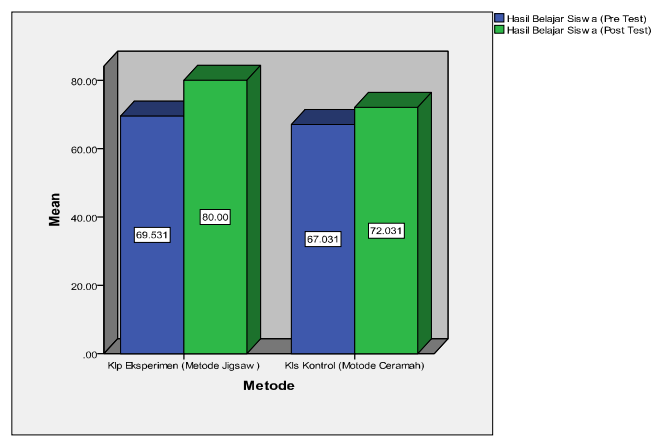

Gambar 2. Diagram Perbandingan Nilai Pre Test dan Post Test

Pembahasan Hasil Penelitian

Penelitian ini bertujuan untuk mengetahui: 1.) Ada tidaknya perbedaan aktivitas belajar IPS siswa menggunakan metode jigsaw dibandingkan menggunakan metode ceramah di Kelas VIII SMP Negeri 1 Masaran Sragen; 2.) Ada tidaknya perbedaan hasil belajar IPS siswa menggunakan metode jigsaw dibandingkan menggunakan metode ceramah di Kelas VIII SMP Negeri 1 Masaran Sragen; 3.) Keefektifan metode Jigsaw terhadap aktivitas belajar dalam pembelajaran IPS Siswa Kelas VIII SMP Negeri 1 Masaran Sragen; dan 4.) Keefektifan metode jigsaw terhadap hasil belajar dalam pembelajaran IPS Siswa Kelas VIII SMP Negeri 1 Masaran Sragen.

Perbedaan Aktivitas Belajar IPS Siswa Menggunakan Metode Jigsaw dibandingkan Menggunakan Metode Ceramah

Hasil penelitian diperoleh nilai t hitung sebesar 2,377 dengan taraf signifikansi 0,021 $<0,05$ pada taraf sig. 5\%, maka Ho ditolak. Penelitian ini berhasil membuktikan hipotesis pertama bahwa terdapat perbedaan aktivitas belajar siswa dalam pembelajaran IPS menggunakan metode jigsaw diban-dingkan menggunakan model ceramah di Kelas VIII SMP Negeri 1 Masaran Sragen. Pemilihan metode pembelajaran merupakan hal yang sangat penting untuk diperhatikan karena metode merupakan salah satu alat untuk mencapai tujuan pembelajaran. Memanfaatkan suatu metode secara akurat, dapat membantu guru dalam mencapai tujuan pembelajaran. Penggunaan metode pembelajaran yang tepat dalam proses belajar mengajar, diharapkan pembelajaran menjadi lebih efektif. Pembelajaran yang efektif akan melatih dan menanamkan sikap demokratis bagi siswa serta menekankan siswa mampu belajar secara mandiri. Penerapan metode pembelajaran yang tepat merupakan solusi supaya aktivitas belajar mengajar menjadi menyenangkan dan mencapai efektivitas.

Salah satu pendekatan pembelajaran yang dapat dilakukan adalah pembelajaran aktif, yaitu dengan model pembelajaran kooperatif. Cooprative learning merupakan suatu metode aktif yang menimbulkan kerja sama yang dapat meningkatkan keterlibatan peserta didik dengan melakukan aktivitas mereka sendiri-sendiri. Cooperative learning memberi kesempatan siswa untuk mengembangkan atau menciptakan ide-ide yang dapat dipelajari sendiri oleh siswa yang akhirnya menambah pengetahuan siswa dibandingkan jika siswa hanya mendengarkan penjelasan dari guru. Jigsaw adalah salah satu tipe model pembelajaran kooperatif yang beranggotakan 4 sampai dengan 
6 orang siswa dengan karakteristik yang heterogen. Materi pembelajaran diberikan kepada siswa dalam bentuk teks. Anggota kelompok bertanggung jawab untuk mempelajari bagian yang sama dan selanjutnya berkumpul untuk saling membantu mengkaji bahan tersebut (Ibrahim, Rachmadiarti, Ismono, \& Nur, 2001, p. 21). Metode pembelajaran jigsaw mengajarkan siswa untuk aktif terlibat dalam pembelajaran dan mampu bekerja sama dengan baik.

Metode pembelajaran kooperatif tipe jigsaw merupakan metode pembelajaran kooperatif, dengan siswa belajar dalam Kelas-Kelas kecil yang terdiri dari 4 - 6 orang secara heterogen dan bekerjasama saling ketergantungan yang positif dan bertanggung jawab atas ketuntasan bagian materi pelajaran yang harus dipelajari dan menyampaikan materi tersebut kepada anggota kelas yang lain (Arends, 1997, p. 37). Jigsaw didesain untuk meningkatkan rasa tanggung jawab siswa terhadap pembelajarannya sendiri dan juga pembelajaran orang lain. Siswa tidak hanya mempelajari materi yang diberikan, tetapi mereka juga harus siap memberikan dan mengajarkan materi tersebut pada anggota yang lain. Siswa akan saling tergantung satu sama lain dan harus bekerja sama secara kooperatif untuk mempelajari materi yang ditugaskan (Lie, 2002, p. 42). siswa dalam Kelas ditugaskan mempelajari salah satu dari komponen yang luas. Setiap siswa bertanggung jawab untuk mengajarkan materi yang dipelajarinya kepada anggota lain. Metode Jigsaw merupakan suatu metode yang dikembangkan oleh Slavin, di dalam metode Jigsaw ada hubungan saling ketergantungan positif antar siswa, ada tanggung jawab perseorangan, serta ada komunikasi antar anggota kelas. Komunikasi yang terjadi di dalam Kelas diharapkan mampu membuat anggota Kelas mengerti dan memahami materi yang didiskusikan bersama. Penggunaan metode Jigsaw bertujuan untuk membuat siswa aktif di dalam kelas dan tidak mudah jenuh dalam menerima materi pelajaran, karena adanya interaksi sosial antara peserta didik dengan bekerjasama dalam Kelas.

Hasil penelitian ini mendukung penelitian sebelumnya yang dilakukan oleh Rijeki Sugestiningsih (2016) tentang "Perbedaan Pengaruh Model Pembelajaran Kooperatif Tipe Jigsaw dan Numbered Heads Together untuk Peningkatan Kerjasama dan Tanggung Jawab Siswa dalam Pembelajaran IPS di SMP Negeri 2 Depok Sleman”. Hasil penelitian menunjukkan bahwa terdapat pengaruh yang signifikan antara model pembelajaran kooperatif tipe Jigsaw dan Numbered Heads Together untuk peningkatan kerjasama siswa dalam pembelajaran IPS di SMP Negeri 2 Depok Sleman.

\section{Perbedaan Hasil Belajar IPS Siswa Menggunakan Metode Jigsaw dibandingkan Menggunakan Metode Ceramah}

Hasil penelitian diperoleh nilai thitung 2,396 dengan taraf signifikansi $0,020<0,05$ pada taraf sig. 5\%, maka Ho ditolak. Uraian tersebut dapat disimpulkan bahwa penelitian ini berhasil membuktikan hipotesis kedua yang menyatakan bahwa terdapat perbedaan hasil belajar siswa dalam pembelajaran IPS menggunakan metode Jigsaw dibandingkan menggunakan metode Ceramah di Kelas VIII SMP Negeri 1 Masaran Sragen. Hasil penelitian menunjukkan bahwa ada perbedaan hasil belajar siswa dalam pembelajaran IPS menggunakan metode jigsaw dibandingkan menggunakan metode ceramah. Hasil belajar merupakan salah satu hal yang penting dalam kegiatan pembelajaran. Hasil belajar digunakan untuk mengetahui sejauh mana siswa memahami materi pelalajaran. Sudjana (2012, p. 22) menjelaskan bahwa hasil belajar adalah kemampuan-kemampuan yang dimiliki siswa setelah siswa menerima pengalaman belajarnya.

Guna mencapai hasil belajar yang maksimal guru memiliki peranan yang penting dalam keberhasilan proses pembelajaran. Guru harus mampu menciptakan suasana belajar yang menarik sehingga siswa bersemangat dalam mengikuti pembelajaran. Guru juga harus memberikan rangsangan yang mampu mendorong siswa agar terlibat secara aktif dalam pembelajaran, sehingga aktivitas belajar meningkat begitu juga dengan hasil belajar siswa juga akan meningkat. Pemilihan metode pembelajaran merupakan hal yang sangat penting untuk diperhatikan guru karena metode merupakan salah satu alat untuk mencapai tujuan pembelajaran. Penerapan metode pembelajaran yang tepat merupakan solusi supaya aktivitas belajar mengajar menjadi menyenangkan dan mencapai efektivitas. Metode pembelajaran kooperatif atau cooperative learning yang dapat diterapkan dalam kegiatan pembelajaran yaitu jigsaw. Metode jigsaw bertujuan untuk membuat peserta didik aktif di dalam kelas dan tidak mudah jenuh dalam menerima materi pelajaran, karena adanya interaksi sosial antara peserta didik dengan bekerjasama dalam kelas. Kerjasama dari para siswa ini pada akhirnya 
dapat meningkatkan hasil belajar siswa. Hasil penelitian ini mendukung penelitian sebelumnya yang dilakukan oleh Suratno (2014) tentang "Keefektifan Pembelajaran Kooperatif Tipe Think-Pair-Share (TPS) dan Tipe Jigsaw pada Materi Bangun Ruang Sisi Lengkung ditinjau dari Prestasi Belajar Matematika dan Karakter Siswa". Hasil penelitian menunjukkan bahwa model pembelajaran kooperatif tipe jigsaw lebih efektif dibanding tipe TPS ditinjau dari prestasi belajar matematika dan karakter siswa SMP Negeri 1 Banjarnegara pada standar kompetensi memahami sifat-sifat tabung, kerucut dan bola, serta menentukan ukurannya.

\section{Keefektifan Metode Jigsaw terhadap Aktivitas Belajar dalam Pembelajaran IPS}

Hasil perhitungan ukuran efek dngan merumuskan rumus Cohen D yaitu sebesar 0,54. Berdasarkan kriteria yang diusulkan Cohen D tentang besar kecilnya ukuran efek diketahui bahwa $(0,2<\mathrm{d}<0,8)$, sehingga dapat disimpulkan bahwa meode jigsaw memberikan efek sedang dalam peningkatan aktivitas belajar siswa. Hipotesis III yang menyatakan bahwa metode jigsaw efektif dalam meningkatkan aktivitas belajar dalam pembelajaran IPS siswa kelas VIII SMP Negeri 1 Masaran Sragen, diterima. Salah satu usaha dalam meningkatkan aktivitas dan hasil belajar siswa yaitu dengan menerapkan metode pembelajaran yang bervariasi karena tidak ada metode yang sempurna sehingga perlu divariasikan dengan model lain. Penelitian ini terdapat dua metode pembelajaran, yaitu metode jigsaw dan metode ceramah. Metode jigsaw merupakan salah satu metode pembelajaran yang dapat memaksimalkan aktivitas dan hasil belajar. Proses pembelajaran dengan metode jigsaw siswa lebih banyak terlibat salah satunya dengan kreasi siswa sendiri, sedangkan metode ceramah merupakan metode yang mengharuskan guru menyampaikan materi secara mendetail dengan kata-kata dan siswa lebih banyak mendengarkan materi yang disampaikan guru.

Wardani (2002, p.87) menguraikan beberapa kelebihan metode pembelajaran kooperatif jigsaw sebagai berikut: 1.) Secara umum, pada metode jigsaw pembelajaran lebih aktif dan saling memberikan pendapat. Suasana belajar lebih kondusif, baru dan adanya penghargaan yang diberikan pada kelas, maka siswa dalam setiap kelas berkompetisi untuk mencapai prestasi yang baik; 2.) Siswa lebih memiliki kesempatan berinteraksi sosial dengan temannya; dan 3.) Siswa lebih aktif dan kreatif serta memiliki tanggung jawab secara individual. Metode jigsaw lebih baik dalam meningkatkan aktivitas belajar siswa dari pada metode ceramah. Asih $(2015$, p. 1) menyebutkan bahwa masih terdapat kecenderungan guru dalam pembelajaran IPS yang menggunakan cara konvensional atau tradisional, sehingga pembelajaran tidak berpusat pada siswa. Minimnya penggunaan metode pembelajaran membuat kegiatan belajar mengajar kurang efektif dan menarik. Metode ceramah yang biasa digunakan oleh guru dalam kegiatan belajar mengajar sering dianggap membosankan oleh siswa dan aktivitas belajar siswa menjadi rendah. Kenyataan yang dapat dilihat masih banyak siswa yang mengobrol dengan teman sebangkunya ketika guru sedang menyampaikan materi pelajaran. Pembelajaran dengan metode ceramah membuat siswa menjadi tidak aktif di dalam kelas.

\section{Keefektifan Metode Jigsaw terhadap Hasil Belajar dalam Pembelajaran IPS}

Hasil perhitungan ukuran efek dengan menggunakan rumus Cohen D yaitu sebesar 0,64. Kriteria yang diusulkan Cohen D tentang besar kecilnya ukuran efek diketahui bahwa $(0,2<\mathrm{d}<0,8)$, sehingga dapat disimpulkan bahwa bahwa metode jigsaw memberikan efek sedang dalam peningkatan hasil belajar siswa. Hipotesis III yang menyatakan bahwa metode jigsaw efektif dalam meningkatkan hasil belajar dalam pembelajaran IPS siswa kelas VIII SMP Negeri 1 Masaran Sragen, diterima. Hasil penelitian menunjukkan bahwa metode jigsaw lebih efektif dalam meningkatkan hasil belajar daripada ceramah. Menurut (Lie, 2002, p. 7), sebagai salah satu model pembelajaran yang kooperatif, Jigsaw mempunyai kebaikan-kebaikan sebagai berikut: 1.) Dapat mengembangkan hubungan antara pribadi positif diantara siswa yang memiliki kemampuan belajar berbeda; 2.) menerangkan bimbingan secara teman; 3.) Rasa harga diri siswa yang lebih tinggi; 4.) Memperbaiki kehadiran; 5.) Penerimaan terhadap perbedaan individu lebih besar; 6.) Sikap apatis berkurang; 7.) Pemahaman materi lebih mendalam; dan 8.) Meningkatkan motivasi belajar.

Salah satu kelebihan dari metode jigsaw adalah meningkatkan pemahaman materi lebih mendalam sehingga dapat meningkatkan hasil belajar siswa, apabila dibandingkan dengan penggunaan metode yang ceramah yang tidak kooperatif dan variatif. Metode ceramah membuat 
keterlibatan atau aktivitas siswa dalam kegiatan belajar berkurang. Banyak siswa yang mengantuk dan tidak memperhatikan saat guru menyampaikan materi pelajaran, kurangnya keberanian siswa dalam mengemukakan ide dan pendapat, sedikit yang aktif bertanya ketika diberi kesempatan oleh guru untuk menanyakan materi pelajaran yang kurang jelas. Guru mulai mengajak diskusi mengenai materi pelajaran, terlihat siswa kurang antusias. Hal ini sesuai dengan penelitian yang dilakukan oleh Pollio (Silberman, 2013, p. 24) yang menunjukkan bahwa dalam pembelajaran dengan metode ceramah, siswa kurang menaruh perhatian selama $40 \%$ dari seluruh waktu pembelajaran. Pembelajaran menggunakan metode jigsaw membuat peserta didik aktif yang menimbulkan kerja sama yang dapat meningkatkan keterlibatan siswa dengan melakukan aktivitas mereka sendiri-sendiri. Cooperative learning memberi kesempatan siswa untuk mengembangkan atau menciptakan ide-ide yang dapat dipelajari sendiri oleh siswa yang akhirnya menambah pengetahuan siswa dibandingkan jika siswa hanya mendengarkan penjelasan dari guru. Pembelajaran dengan cara seperti ini membuat hasil belajar siswa juga semakin meningkat.

\section{SIMPULAN}

Berdasarkan hasil pembahasan dan analisis statistik didapatkan kesimpulan bahwa: 1.) Terdapat perbedaan aktivitas belajar siswa dalam pembelajaran IPS menggunakan metode jigsaw dibandingkan menggunakan metode ceramah di kelas VIII SMP Negeri 1 Masaran, Sragen; 2.) Terdapat perbedaan hasil belajar siswa dalam pembelajaran IPS menggunakan metode jigsaw dibandingkan menggunakan metode ceramah di kelas VIII SMP Negeri 1 Masaran, Sragen; 3.) Efektivitas pembelajaran metode jigsaw untuk meningkatkan aktivitas belajar siswa tergolong sedang. Metode jigsaw dapat dikatakan efektif dalam meningkatkan aktivitas belajar siswa dibandingkan menggunakan metode ceramah pada pembelajaran IPS di kelas VIII SMP Negeri 1 Masaran, Sragen; dan 4.) Efektivitas pembelajaran metode jigsaw untuk meningkatkan hasil belajar siswa tergolong sedang. Metode jigsaw dapat dikatakan efektif dalam meningkatkan hasil belajar siswa dibandingkan menggunakan metode ceramah pada pembelajaran IPS di Kelas VIII SMP Negeri 1 Masaran, Sragen.

\section{DAFTAR PUSTAKA}

Ardalan, K., \& College, M. (2013). The philosphical foundation of the lecture method of instruction and the case method of instruction: Implications for examinations. Contemporary Issues in Education Research, 6(1), 1-8. Doi: https://doi.org/10.19030/cier.v6i1.7599

Arends, R. (1997). Classroom instructional management. New York: The Mc graw-Hill Company.

Asih, E. (25 Juni 2015). Pentingnya pembaharuan strategi, metode dan teknik pembelajaran. Kompasiana, hlm.1.

Dollard, M. W., \& Mahoney, K. (2010). How effective is the jigsaw method when used to introduce new science curricula in middle school science?. Ontario Action Researcher, 10(3).

Donald, K.. \& Eggen, P. (1940). Learning and teaching: Research based methods. Boston: Library of Congress Cataloging in Publication Data.

Elmgren, M., Ho, F., Akesson, E., Schmid, S., \& Towns, M. (2014). Comparison and evaluation of learning outcomes from an international perspective: Development of a best-practice process. Journal of Cemical Education, 92(3). doi:http://dx.doi.org/10.1021/ed500542b

Er, H. (2017). The impact of teaching the subjects under "science in time" unit in the social studies class in the 7th grade using jigsaw technique on the academic success of the students. Universal Journal of Educational Research, 5(5), 838-847. doi: https://doi.org/10.13189/ujer.2017.050516

Gurvitch, R., \& Metzler, M. (2013). aligning learning activities with instructional models. Journal of Physical Education, Recreation \& Dance, 84(3), 30-37. doi:http://dx.doi.org/0.1080/07303084.2013.767719 
48 - Harmoni Sosial: Jurnal Pendidikan IPS

Hamalik, O. (2011). Kurikulum dan pembelajaran. Jakarta: Bumi Aksara.

Hasibuan, J. J. (2004). proses belajar mengajar. Bandung: Remaja Rosdakarya.

Ibrahim, M., Rachmadiarti, F., Ismono, I., \& Nur, M. (2000). Pembelajaran kooperatif. Surabaya: UNESA University Press.

Lie, A. (2002). Cooperative learning. Jakarta: Grasindo.

Mohammadjani, F., \& Tokaboni, F. (2015). A comparison between the effect of cooperative learning teaching method and lecture teaching method on students' learning and satisfication level. International Education Studies, 8(9), 107-112. doi:http://dx.doi.org/10.5539/ies.v8n9p107

Molstad, C. E., \& Karseth, B. (2016). National curricula in Norway and Finland: The role of learning outcomes. European Educational Research Journal, 15(3), 329-344. doi:http:dx.doi.org/10.1177/1474904116639311

Naga, D. S. (2009). 64 Rumus terapan probabilitas dan sekor pada hipotesis statistika. Jakarta: Grasindo.

Purwanto, P. (2011). Statistika.untuk penelitian. Yogyakarta: Pustaka Pelajar.

Riduwan, R. (2011). Belajar mudah penelitian untuk guru-karyawan dan peneliti pemula. Bandung: Alfabeta.

Sagala, S. (2009). Konsep dan makna pembelajaran untuk membantu memecahkan problematika belajar dan mengajar. Bandung: Alfabeta.

Sardiman, A. M. (2010). Interaksi dan motivasi belajar mengajar. Jakarta: Raja Grafindo Persada.

Silberman, M. (2013). Active learning 101 strategi pembelajaran aktif. Yogyakarta: Pustaka Insan Madani.

Singer, A. J. (2009). Social studies for secondary school: Teaching to learn, learning to teach. New York: Dodd and Company.

Soekartawi, S. (1995). Meningkatkan efektivitas mengajar. Jakarta: Dunia Pustaka Jaya.

Soewandi, S. A. M., Widharyanto, B., Bram, B., \& Nugroho, Y. F. S. T. (2008). Perspektif Pembelajaran Berbagai Bidang Studi. Yogyakarta: Penerbit Universitas Sanata Darma.

Sudjana, N. (2012). Penilaian hasil proses belajar mengajar. Bandung: Remaja Rosdakarya.

Sugiyono, S. (2010). Metode kuantitatif, kualitatif dan RnD. Bandung: Alfabeta.

Supardi, S. (2011). Dasar-dasar ilmu sosial. Yogyakarta: Penerbit Ombak

Trianto, T. (2012). Model pembelajaran terpadu. Jakarta: Bumi Aksara..

Wilujeng, K. (2015). Penerapan metode pembalajaran bermain peran pada mata pelajaran IPS untuk meningkatkan hasil belajar siswa kelas IIIB SDN Semboro 01 Kecamatan Semboro Kabupaten Jember. Jurnal Pendidikan, 4(4). 113-124. 